\title{
The Nordic Arrest Warrant finally in force
}

\author{
Annika Suominen $^{\star}$
}

On 16th November 2012, the Convention on surrender on the basis of an offence between the Nordic States, the Nordic Arrest Warrant $(N A W)^{1}$ finally entered into force for all the Nordic states, Denmark, Finland, Iceland, Norway and Sweden. Subsequently, the national acts implementing the convention also entered into force on that date, as is typical for conventions, when the conventions enter into force, so does the national implementing legislation. ${ }^{2}$ Although the Nordic states had amended their legislation accordingly before this date, they were waiting for the convention to enter into force for the national acts becoming applicable. An exception of this was the Finnish act, which had already been in force since 2008. The reason for this was merely practical, it was considered feasible to have only one act regulating Nordic arrest warrants in force at the same time. This created, however, a peculiar situation in relation to those arrest warrants received during this time, when the other Nordic states did not yet apply the $N A W$.

\section{On the NAW in general}

The Nordic Arrest Warrant regulates surrender between the Nordic States. The NAW is a result of Nordic cooperation on extradition traditionally having been more far reaching than the rules on extradition with other states (including other EU Member States). The Nordic states concluded, after the European Arrest Warrant $(E A W)^{3}$ was agreed, in a Nordic ministerial meeting that an agreement on enhanced cooperation in extradition should be established. ${ }^{4}$ The EAW makes this possible, as pursuant to it, Member States can conclude bilateral or multilateral agreements after the EAW has come into force, as long as these agreements extend or enlarge the scope of the EAW and help to simplify or facilitate further the surrender of persons. ${ }^{5}$ The idea was therefore to reform intra-Nordic extradition, as

\footnotetext{
* Postdoctoral research fellow, Faculty of Law, University of Bergen.

${ }^{1}$ Convention of 15.12.2005 on surrender on the basis of an offence between the Nordic States (The Nordic Arrest Warrant)

2 The Danish amendments were made with amendment 394/2007 and entered into force with BEK nr 987 of 04/ 10/2012, the Finnish Act 1383/2007, January 1st 2008 and the convention entered into force with decree 72/2012, The Icelandic amendments were made with Act 12 of 25th February 2010, in force pursuant to section 23, the Norwegian amendments were made with Act 2012-01-20-4 and the Swedish amendments with Act 2011:1165.

${ }^{3}$ The Council Framework Decision 2002/584/JHA of 13 June 2002 on the European arrest warrant and the surrender procedures between Member States, OJ L 190/1, 18.07.2002, amended with Council Framework Decision 2009/299/JHA of 26 February 2009 amending Framework Decisions 2002/584/JHA, 2005/214/JHA, 2006/783/ JHA, 2008/909/JHA and 2008/947/JHA, thereby enhancing the procedural rights of persons and fostering the application of the principle of mutual recognition to decisions rendered in the absence of the person concerned at the trial, OJ L 81/24, 27.3.2009.

${ }^{4}$ Explanatory memorandum to the NAW p. 1 and Suominen, The principle of mutual recognition in cooperation in criminal matters, a study of the principle in four framework decisions and in the implementation legislation in the Nordic Member States, Intersentia 2011p. 81-82.

${ }^{5}$ Article 31(2) EAW, and Suominen, op. cit. 2011 p. 81.
} 
had the Nordic Member States been obliged to use the EAW among them, this could have been a drawback. The previous Nordic cooperation system functioned well in practice and was also more extensive in some ways. ${ }^{6}$ The impact of the EAW is easy to see in the convention signed in 2005.

\section{What is a Nordic Arrest Warrant}

A Nordic arrest warrant is defined as a judicial decision issued by a Nordic state with the aim of arresting and surrendering a requested person from another Nordic State, for the purposes of conducting a criminal prosecution or executing a custodial sentence or detention order. ${ }^{7}$ A Nordic arrest warrant can be issued for any offence punishable with a custodial sentence or detention order, as there is no requirement regarding the severity of the sanction. The idea of the form in the EAW is also used in the NAW. A form is attached to the convention which is to be used in the surrender cases. This form is similar to the form of the EAW, but the NAW form lacks some points due to its simpler form of surrender. ${ }^{8}$ Pursuant to Articles 3(1) and 3(2) NAW, the competent judicial authorities are defined according to the laws of the issuing and executing states. There is furthermore a possibility to designate a central authority to assist the competent judicial authorities pursuant to Article 3(3) NAW. The NAW uses the new terminology of surrender (överlämna) and it replaces all previous extradition instruments between the Nordic states (both the previous Nordic extradition regime as well as the EAW). This means that from 16th October 2012 onwards, the Nordic states apply the Nordic arrest warrant between themselves.

\section{Time limits}

A Nordic arrest warrant is to be executed without a delay. If the person sought consents to his surrender, the decision on execution of the arrest warrant is to be taken at latest 3 days after consent. ${ }^{9}$ In other situations, the decision on surrender is to be taken at the latest 30 days after the person has been arrested. If these time limits cannot be observed, the issuing state shall be informed of the delayed and the decision on surrender is then to be taken as soon as possible. ${ }^{10}$ The NAW shortens the time limits for surrender even further than the EAW. Although the NAW is

\footnotetext{
${ }^{6}$ Mathisen: Nordic Cooperation and the European Arrest Warrant: Intra-Nordic Extradition, the Nordic Arrest Warrant and Beyond. Nordic Journal of International Law 79 (2010) p. 17 and on the position of Norway as part of the Schengen see Suominen: EU criminal law cooperation before and after the Lisbon Treaty - aspects and comments especially in relation to the Norwegian position, article under publication in JFT 6/2012.

${ }^{7}$ Article 1(1) NAW.It is defined completely in the same was as an arrest warrant in the EAW, see Suominen 2011 op. cit. p. 81 .

${ }^{8}$ The points (d), (f) and (h) of the EAW certificate are not in the NAW certificate, and in relation to point (e) there is no list of offences, as the requirement of double criminality is abolished.

${ }^{9}$ Articles 14(1) and 14(2) NAW.

${ }^{10}$ Articles 14(3) and 14(4) NAW.
} 
almost a copy of the EAW, this is only one way in which the NAW goes further than the EAW, as can be seen in the next part of this article. Furthermore, a refusal of a Nordic arrest warrant is to be justified pursuant to Article 14(6) NAW. This entails that in cases where a Nordic arrest warrant is to be refused, this should be duly motivated. Inter-Nordic surrender will therefore become more efficient in the sense that in situations where an arrest warrant is refused, it should be justified, and a ground for refusal shall be applicable. This will be made within the time limits mentioned above.

\section{The differences between the NAW and the EAW}

As already mentioned above, the NAW can be issued for any offence and there is no requirement as regards the severity of the sanction (which the EAW includes). In addition to this, the NAW applies different (stricter) time limits. The NAW furthermore completely abolishes the requirement of double criminality as a main rule. This means that inter-Nordic surrender is to take place generally even though the requirement of double criminality is perhaps not fulfilled. Double criminality is not to be checked at all (a small exception still applies in relation to situations where the offence has been committed (partly or wholly) in the executing Nordic state), ${ }^{11}$ which can be seen as an expression of mutual trust between the Nordic states and a result of similar criminal policies in these states. ${ }^{12}$

The NAW makes no exception as regards the surrender of own nationals. There is no mandatory ground for refusal, but the optional ones resemble those of the EAW, where not only nationality, but also residence and staying in the state of execution are relevant. ${ }^{13}$ The NAW furthermore enables a broader prosecution for offences committed prior to the surrender, as there is no general prohibition to prosecuting the person for more offences than those for which he was surrendered, but Article 23 stipulates some exceptions to this, such as if a mandatory ground for refusal could have been evoked. ${ }^{14}$

The NAW further contains fewer optional grounds for refusal than the EAW. Those absent from the NAW (compared to the EAW) are the grounds for refusal concerning the double criminality requirement, which cannot be used as a ground for refusal for taxes or other national duties, statute-barring of criminal prosecution or punishment and extraterritoriality as a ground for refusal. ${ }^{15}$ Excluding the

\footnotetext{
${ }^{11}$ Pursuant to article 5(2) NAW.

12 Suominen 2011 op. cit. p. 41-43.

${ }^{13}$ Pursuant to Article 5(5) NAW surrender may be refused if the Nordic arrest warrant is issued for execution of a custodial sentence and the person subject to the arrest warrant is staying in, is a national of or a resident in the executing state. This article corresponds to Article 4(6) EAW. Following Article 6 NAW the execution of a Nordic arrest warrant for prosecution may, if the requested person is a national or resident in the executing state, be subject to the condition to the return of the person to the executing Member State after being heard so that he may serve any custodial sentence or detention order of the issuing state. This article corresponds to Article 5(3) EAW.

14 This broader possibility is mentioned in the Explanatory memorandum to the NAW p. 2.

${ }^{15}$ The grounds for refusal of the EAW that are not found in the NAW are the ones in Articles4(1), 4(4) and 4(7)(b) EAW.
} 
ground for refusal in relation to the double criminality requirement in general was already mentioned above, and the extension in relation to national duties follows this logic. Excluding the ground for refusal in relation to statute-barring is not further commented on, but can perhaps be considered a result of quite similar rules on statute-barring of criminal prosecution in the Nordic states. ${ }^{16}$ Not applying the ground for refusal in relation to extraterritorial jurisdiction is not commented on in the explanatory memorandum, but can be considered based on previous cooperation that has not applied this as a ground for refusal. ${ }^{17}$

\section{Briefly on Nordic cooperation}

Nordic cooperation in criminal matters is based on a high degree of similarity between Nordic legislation and an existing mutual trust. Nordic cooperation can be considered as having three different aims, which are a) to exchange information, b) to have a common, comprehensive objective for legislation, or c) to have similar legislation. ${ }^{18}$ This often results in criminal policies of a similar nature, but at the same time allowing for differences and taking the national differences into account.

Although the NAW was agreed on as a convention, which might be considered exceptional in a Nordic setting which usually prefers more informal agreements regulating Nordic cooperation, the NAW is considered as step forward in the development of the Nordic criminal law community. The rather lengthy period of time before becoming applicable law between the Nordic states is explained by using the form of a convention, as the convention did not become applicable before all parties having ratified it. Today, this is luckily reality.

Nordic cooperation is based on mutual respect for state sovereignty and is often looked at as a role model in relation to EU cooperation in criminal matters. However, there are some differences which do not allow for applying the Nordic model freely on cooperation, or more specifically mutual recognition within the EU. ${ }^{19}$ Mutual recognition in the Nordic states is based on criminal legislation, which is very similar and can be considered harmonised to a certain extent, especially as this is based on a criminal policy, which again is similar in many ways, founded as it is on similarities between Nordic societies. One could therefore say that the starting point for Nordic cooperation is different, as the Nordic countries have to some extent similar societies with similar languages, cultures and are geographically proximate. This leads to having, or at least laying the ground for genuine mutual trust between the Nordic countries. Based on long traditions of cooperation, harmonised criminal legislation and cultural and legal similarities

\footnotetext{
${ }^{16}$ The Explanatory memorandum to the NAW p. 5 only briefly mentions this.

${ }^{17}$ On Nordic rules on jurisdiction, see e. g. Straffrättsligjurisdiktion i Norden, Nord 1992:17and Jurisdiction in the Nordic Countries (eds. Elholm, Feldtmann and Greve), Jurist- og ØkonomforbundetsForlag, under publication 2014.

${ }^{18}$ Suominen 2011 op. cit. p. 41-42.

${ }^{19}$ The comparison between EU and Nordic cooperation in criminal matters is based on Suominen 2011 op. cit. p. 64-66.
} 
between the Nordic states, mutual trust in EU criminal cooperation cannot be comparable to this. ${ }^{20}$

There are other differences as well. In relation to the aim of cooperation, the Nordic cooperation can be considered more focused on establishing and evolving a cultural and legal community than the EU. Naturally, this is also due to different possibilities and settings, but the area of freedom, security and justice cannot in the same sense be considered as establishing a cultural and legal area. The basis for cooperation (in addition to mutual trust) seems correspondingly different. The mutual recognition between the Nordic states is based on a will to co-operate. This will is essential for cooperation. This means that the starting point in the Nordic setting is different. Mutual recognition in EU criminal law entails that recognition is to take place, unless a ground for refusal can be applied. There is an obligation to mutually recognised decisions of other Member States. As the starting points are different, it is natural that the outcomes differ furthermore to some extent. This is further linked to the institutional concept of cooperation. Whereas the Nordic cooperation usually favours informal agreements that ultimately lead to similar legislation and avoiding institutional aspects, the EU has well-established institutional rules and procedures for cooperation as well as a common court, the CJEU.

\footnotetext{
${ }^{20}$ On more detailed analysis of mutual trust in the EU criminal law setting, see Suominen 2011 op. cit. p. 47-51.
} 